\title{
Elevated AGE-Modified ApoB in Sera of Euglycemic, Normolipidemic Patients with Atherosclerosis: Relationship to Tissue AGEs
}

\author{
Alan William Stitt, ${ }^{*}$ Cijiang He, ${ }^{*}$ Steven Friedman, ${ }^{\dagger}$ \\ Larry Scher, ${ }^{\dagger}$ Peter Rossi, ${ }^{+}$Larry Ong, ${ }^{\dagger}$ Hank Founds, ${ }^{\ddagger}$ \\ Yong Ming Li,* Richard Bucala,* and Helen Vlassara* \\ *The Picower Institute for Medical Research, Manhasset, New York, U.S.A. \\ ${ }^{\dagger}$ North Shore University Hospital, Manhasset, New York, U.S.A. \\ ${ }^{\ddagger}$ Alteon Inc., Ramsey, New Jersey, U.S.A.
}

\begin{abstract}
Background: Advanced glycation endproducts (AGEs) are implicated in the pathogenesis of atherosclerotic vascular disease of diabetic and nondiabetic etiology. Recent research suggests that advanced glycation of ApoB contributes to the development of hyperlipidemia. AGEspecific receptors, expressed on vascular endothelium and mononuclear cells, may be involved in both the clearance of, and the inflammatory responses to AGEs. The aim of this study was to examine whether there is a relationship between serum AGE-ApoB and AGEs in arterial tissue of older normolipidemic nondiabetic patients with occlusive atherosclerotic disease, compared with age-matched and younger asymptomatic persons. Materials and Methods: Serum AGE-ApoB was measured by ELISA in 21 cardiac bypass patients. Furthermore, an AGE-specific monoclonal antibody, and polyclonal antibodies against anti-AGE-receptor (antiAGE-R) 1 and 2 were used to explore the localization and distribution of AGEs and AGE-R immunoreactivity (IR) in arterial segments excised from these patients. Results: Serum AGE-ApoB levels were significantly elevated in the asymptomatic, older population, compared with those in young healthy persons $(259 \pm 24$ versus
\end{abstract}

$180 \pm 21$ AGE U/mg of ApoB, $p<0.01$ ). Higher AGEApoB levels were observed in those patients with atherosclerosis $(329 \pm 23$ versus $259 \pm 24 \mathrm{AGE} \mathrm{U} / \mathrm{mg}$ ApoB, $p<0.05)$. Comparisons of tissue AGE-collagen with serum AGE-ApoB levels showed a significant correlation $(r=0.707, p<0.01)$. In early lesions, AGE-IR occurred mostly extracellularly. In fatty streaks and dense, cellular atheromatous lesions, AGE-IR was visible within lipid-containing smooth muscle cells and macrophages, while in late-stage, acellular plaques, AGE-IR occurred mostly extracellularly. AGE-R1 and -R2 were observed on vascular endothelial and smooth-muscle cells and on infiltrating mononuclear cells in the earlystage lesions, whereas in dense, late-stage plaques, they colocalized mostly with lipid-laden macrophages. On tissue sections, scoring of AGE-immunofluorescence correlated with tissue AGE and plasma AGE-ApoB.

Conclusions: (1) The correlation between arterial tissue AGEs and circulating AGE-ApoB suggests a causal link between AGE modification of lipoproteins and atherosclerosis. AGE-specific receptors may contribute to this process. (2) Serum AGE-ApoB may serve to predict atherosclerosis in asymptomatic patients.

\section{INTRODUCTION}

The nonenzymatic glycation of proteins is a spontaneous process that eventually culminates in formation of cross-linking advanced glycation

Address correspondence and reprint requests to Dr. Helen Vlassara, The Picower Institute for Medical Research, Manhasset, NY 11030, U.S.A. Phone: 516-562-9501; Fax: 516-562-9516; e-mail: hvlassara@picower.edu endproducts (AGEs). AGE formation in vivo has been implicated in the pathogenesis of diabetic complications and aging, especially in vascular and renal deterioration (1-4). More recently, AGEs have emerged as direct contributors to the formation and acceleration of atherosclerotic lesions independent of diabetes (5-7). It is recognized that these highly reactive molecules can 
cause thickening and rigidity of the vascular wall $(8,9)$, interfere with nitric oxide (NO)-mediated vasodilatation (10), and induce secretion of cytokines and growth factors (11), phenomena that are known contributors to atherosclerosis (12). In addition, AGE modification of circulating low-density lipoprotein (LDL), occurring on both the lipid $(13,14)$ and ApoB components $(15)$, is under investigation as a natural mechanism of atherogenesis, because of clinical evidence of significantly elevated AGE-ApoB in diabetic patients with renal complication (16).

Recently, this laboratory has characterized a group of novel AGE receptors, comprising three AGE-binding proteins previously sequenced and identified as AGE-R1/OST-48, AGE-R2/80K-H, and AGE-R3/galectin-3 (17-19). Other membrane-associated and soluble AGE-binding proteins include RAGE, a $35-\mathrm{kD}$ protein $(20)$, lactoferrin $(21)$, and lysozyme $(21,22)$, expanding the number of proteins involved with AGE processing by a variety of mechanisms. AGE receptors are expressed on many cell types, including endothelial cells, monocytes, lymphocytes, and smooth muscle cells (18), and while they likely play a role in the uptake and intracellular processing of AGE-modified, senescent molecules, they may also account for many of the adverse cellular responses mentioned above $(1,23,24)$.

In this study, we have compared the levels of plaque AGE and serum AGE-ApoB in nondiabetic, normolipidemic patients with carotid atherosclerotic lesions, hospitalized age-matched patients without clinical evidence of carotid atherosclerotic lesions, and young, normal controls. We have also investigated the immunolocalization of AGEs and AGE receptors AGE-R1 and -R2 in specific cell types within atherosclerotic plaques of nondiabetic patients.

\section{MATERIALS AND METHODS}

\section{Clinical Subjects}

Carotid or femoral plaques were excised during routine bypass surgery of 21 nondiabetic patients (mean age: $68.5 \pm 8.2 \mathrm{yr} ; 15$ male, 6 female) with atherosclerotic occlusive disease established by arteriography. Blood samples were also collected after an overnight fast from these patients as well as from aged-matched, asymptomatic patients (mean age: $62.3 \pm 11.4 ; 4$ male, 3 female) and young volunteers (mean age: $28 \pm 4$ ). The criteria for study inclusion were normal plasma cholesterol and tryglycerides, and no history of diabetes, hypertension, renal disease, or obesity. All patients (with or without atherosclerosis) had a positive history of smoking, past or presently active, but none of the young volunteers were smokers. Tissue samples from all 21 patients with atherosclerosis were processed for quantitation of vessel wall AGEs to establish a correlation with serum AGE-ApoB levels; 10 of these tissue samples were randomly selected and processed for detailed histological studies.

\section{Antibodies}

Monoclonal antibodies raised against AGE-KLH and polyclonal antisera against recombinant AGE-R1/OST and AGE-R2/80K-H were used as previously described (25). IgG fractions of preimmune sera and immune sera against OST-48 and $80 \mathrm{~K}-\mathrm{H}$ were purified by protein-G columns (Pharmacia, Piscataway, NJ). The specificity of these antibodies has been confirmed by Western blot and titers were above $1: 10,000$ as estimated using a conventional ELISA. Antibodies against specific leukocyte markers were purchased from Dako, Inc. (Carpinteria, CA; see Table 2) and anti-von Willebrand Factor antibody was purchased from Sigma Immunochemicals, Inc. (St. Louis, MO).

\section{Immunocytochemistry}

Freshly obtained carotid arteries were processed by immersion in ornithine carbamoyltransferase (OCT) compound (Miles Inc., Elkhart, IN) and snap-freezing in viscous isopentane (cooled with liquid nitrogen). Fresh frozen sections were cut at $8 \mu \mathrm{m}$, fixed in cold acetone for $20 \mathrm{~min}$, and stored at $-80^{\circ} \mathrm{C}$. A representative number of sections were stained with hematoxylin and eosin (H\&E) or hematoxylin/Oil red O for routine histology.

Prior to immunocytochemistry, the sections were hydrated in phosphate-buffered saline (PBS) containing $0.1 \%$ bovine serum albumin (BSA), $0.01 \%$ Triton $\mathrm{X}-100$, and $0.01 \%$ sodium azide (Sigma). Before addition of the primary antibody, the sections were incubated in $10 \%$ normal goat serum (NGS; GIBCO-BRL, Gaithersburg, MD) for 20 min. Optimal titration of the primary antibodies was determined by serial dilution of each antibody on similar tissue sections in a pilot study. Following incubation in the primary antibody for $18 \mathrm{hr}$ at $4^{\circ} \mathrm{C}$, sections were washed in PBS (three 10-min rinses) and then exposed to the appropriate biotinylated goat anti-rabbit or anti-mouse secondary antibody 
TABLE 1. Leukocyte identification in atherosclerotic lesions

\begin{tabular}{|c|c|c|c|c|}
\hline \multirow[b]{2}{*}{ Lesion Category } & \multicolumn{4}{|c|}{ Leukocyte Cell-Specific Antibodies } \\
\hline & $\begin{array}{c}\text { L26 } \\
\text { B Lymphocyte }\end{array}$ & $\begin{array}{l}\text { UCHL-1/OPD4 } \\
\text { T Lymphocyte }\end{array}$ & $\begin{array}{c}\text { HAM-56 } \\
\text { Macrophage }\end{array}$ & $\begin{array}{c}\text { LCA } \\
\text { Leukocyte }\end{array}$ \\
\hline Early & - & + & $\begin{array}{c}+ \\
\text { (in subendothelium) }\end{array}$ & $\begin{array}{c}+ \\
\text { (within intima) }\end{array}$ \\
\hline Intermediate & - & $\begin{array}{c}+++ \\
\text { (in recanalizing vessels } \\
\text { and plaque regions) }\end{array}$ & $\begin{array}{c}+++ \\
\text { (in plaque regions, } \\
\text { and subendothelium) }\end{array}$ & $\begin{array}{c}++ \\
\text { (in plaque regions, } \\
\text { and subendothelium) }\end{array}$ \\
\hline Late (calcified) & - & + & $\begin{array}{c}+++ \\
\text { ( in center of plaque) }\end{array}$ & $\begin{array}{c}++ \\
\text { (in center of plaque) }\end{array}$ \\
\hline
\end{tabular}

Leukocyte identification ranged from none $(-)$ to intense $(+++)$.

(Amersham, Arlington Heights, IL) for $1 \mathrm{hr}$. After washing, the sections were incubated with streptavidin FITC (Amersham) for a further $1 \mathrm{hr}$. After another washing, sections were then mounted in $50 \%$ aqueous glycerol and photographed with an Olympus (Model PM-10ADS) fluorescence microscope.

AGE-immunoreactivity (AGE-IR) in each specimen was semi-quantified using an arbitary scale of (-) (no immunoreactivity) to $(+++$ ) (intense immunostaining) in a blinded fashion. Control sections were processed using a similarly diluted mouse or rabbit preimmune IgG at the primary antibody stage.

For preabsorbed controls, optimally diluted antibody to AGE was mixed with an equal volume of $100 \mu \mathrm{g} / \mathrm{ml}$ BSA-AGE for $1 \mathrm{hr}$ prior to incubation before being placed onto sections. BSA-AGE was prepared in vitro as previously described (18).

\section{Sample Processing}

Serum samples had been stored at $-70^{\circ} \mathrm{C}$ prior to analysis. Prior to assaying, sera were diluted 1:5 with dilution buffer (PBS, 0.05\% Tween-20 and $1 \mathrm{mM} \mathrm{NaN}_{3}$ ) and then subjected to an AGEspecific ELISA (25).

Plasma LDL and AGE-ApoB fractions were isolated from all blood samples as described (1315). Briefly, plasma LDL was isolated by sequential ultracentrifugation and the $A p o B$ and lipid components were separated by extracting LDL with cholorform:methanol (1:1, vol/vol) and pelleting the denatured apoproteins by microcentrifugation. After washing in distilled water, 2-4 $\mathrm{mg}$ of apoprotein was incubated with $1 \mathrm{mg}$ of proteinase $\mathrm{K}$ for $18 \mathrm{hr}$ at $37^{\circ} \mathrm{C}$. The ApoB-AGE content was measured by a competitive ELISA (see below).

Freshly endarectomized carotid and femoral arteries were snap frozen in liquid nitrogen and stored at $-80^{\circ} \mathrm{C}$. Before processing, the arterial tissue was slowly thawed, rinsed with PBS, and finely minced with scissors. The tissue protein was extracted and digested according to the method of Makita et al. (26). Briefly, lipids were extracted with acetone/chloroform (1:1, vol/vol) by shaking gently overnight at $4^{\circ} \mathrm{C}$. The samples were then dried by vacuum centrifugation and resuspended in $0.2 \mathrm{M}$ sodium phosphate buffer (pH 7.4). Collagenase (type VII) was then added to a $1: 100(\mathrm{w} / \mathrm{w})$ ratio and the mixture incubated for $48 \mathrm{hr}$ at $37^{\circ} \mathrm{C}$ with gentle shaking. One drop of toluene was added to maintain sterility. Digested samples were then used for AGE ELISA and hydroxyproline measurements $(25,26)$.

\section{AGE-ApoB ELISA}

Total serum AGE-ApoB levels were measured by a sandwich AGE-ELISA as described $(16,25)$, using an anti-AGE monoclonal antibody (4G9) (kindly provided by Alteon Inc., Ramsey, NJ) immobilized on microtiter plates, and a polyclonal, horseradish peroxidase-conjugated antiApoB antibody (HRP-anti-ApoB) (Biodesign, Kennebunkport, ME) (1:500). Briefly, wells were coated with $4 \mathrm{G} 9$ ( $1.5 \mu \mathrm{g} /$ well), followed by the addition of serum $(100 \mu \mathrm{l}), 0.9 \mathrm{ml}$ polyethylene glycol (PEG) (6.66\%) (Sigma), and $100 \mu \mathrm{l}$ $0.05 \%$ sodium dodecyl sulfate in PBS for $10 \mathrm{hr}$ at 
$28^{\circ} \mathrm{C}$, after which HRP-anti-ApoB $(100 \mu \mathrm{l})$ was added for $1 \mathrm{hr}$ at $37^{\circ} \mathrm{C}$. One hundred microliters of OPD (Sigma) was added prior to reading optical density (OD) at $450 \mathrm{~nm}$. Total serum ApoB was determined by the Incstar SPQ Test System (Incstar Corp., Stillwater, MN).

\section{Statistics}

Differences in serum AGE-ApoB levels between the groups were compared with the unpaired $t$ test. Regression analysis was used to examine the correlation between serum AGE-ApoB, tissue AGE-collagen, and immunofluorescence scoring. All data were expressed as mean \pm SD.

\section{RESULTS}

\section{Histochemistry}

H\&E and Oil-red-O-stained sections revealed the extent of plaque formation in the excised segments. Some specimens, which were sectioned in regions exhibiting early atheroma, clearly demonstrated thickening of the intimal layer, cellular infiltration, and lipid accumulation, whereas the endothelium remained intact. Sectioning through the middle of the excised vascular segment showed in all specimens characteristic areas of extreme atherosclerotic plaque, demonstrating their heterogeneous nature, with large numbers of densely packed cells in some areas, while adjacent areas revealed fibrosed or calcified acellular lesions.

\section{Immunocytochemistry}

The identity of the endothelium was confirmed by von Willebrand factor immunoreactivity in adjacent sections, while the leukocytes were identified by a battery of immunospecific cell markers (Table 1).

Tissue sections from the early stages of plaque formation revealed intense extracellular AGE-IR in the thickened intimal layers and subintimal extracellular matrix (ECM) in 8 out of 10 patients (Fig. 1A, B). In most setions, smooth muscle cells and infiltrating macrophages were immunoreactive for AGE, although AGE-positive macrophages were always more numerous than AGE-positive smooth muscle cells. In morphologically typical fatty streak lesions, AGE-IR colocalized with intracellular lipid deposits in both cell types (Fig. 1C). In sections made through a completely occluded vessel with atherosclerotic plaque, AGE-IR was present within large numbers of macrophages at the center of the lesion (Fig. 1D). In the fibrosed acellular regions of many late-stage, dense plaques, extracellular AGE-IR was observed, often in close spatial proximity to extracellular lipid. In such cases, AGE-IR was diffuse in nature and associated with the cell debris characteristic of these regions. The semi-quantified AGE-IR recorded for each specimen is presented in Fig. 5 .

In the same series of sections, AGE-receptor immunoreactivity (AGE-R-IR) was localized to the endothelium, smooth muscle cells, and to monocytes adhering to the surface and infiltrating the thickened intimal layers (Fig. 2). In early lesions, both AGE-R1 (left) and -R2 (right) were abundant in cells of the thickened intima with a similar pattern of distribution. It was apparent that within monocytes, AGE-R1 staining was consistently more intense than AGE-R2. In contrast, in the endothelial cells, AGE-R2 was more intensely stained. In sections through the vasa vasorum of a carotid artery, both AGE-Rl and -R2 stained strongly positive within smooth muscle and endothelial cells (Fig. 2C, left and

FIG. 1. AGE-immunoreactivity (AGE-IR) in human carotid arteries from non-diabetic patients

(A) Left: Section through the pre-atherosclerotic region of an excised carotid artery segment. There is strong AGE-IR in the internal elastic lamina and extracellular matrix layers of the vessel wall. (magnification $\times 100$ ) Right: Corresponding to lA left, showing staining with a non-immune IgG-serum. Only autofluorescence is evident in the vessel wall. (magnification $\times 100)(B)$ Left: Carotid artery showing a characteristically thickened intima with focal areas of intense AGE-IR. (magnification $\times 200$ ) Right: Same as on left panel, stained with a nonimmune IgG serum. (magnification $\times 200$ ) (C) Left: A fatty-streak lesion with proliferating smooth muscle cells, showing intense cytoplasmic AGE-IR. (magnification $\times 200$ ) Right: IgG-control of corresponding section to left panel with lipid-derived autofluorescence within the smooth muscle cells. (magnification $\times 200$ ) (D) Left: Section through a completely occluded atherosclerotic plaque showing AGE-IR contained within macrophages at the center of the lesion. (magnification $\times 200$ ) Right: Corresponding section to left panel, stained with IgG-control serum. (magnification $\times 200)$ 

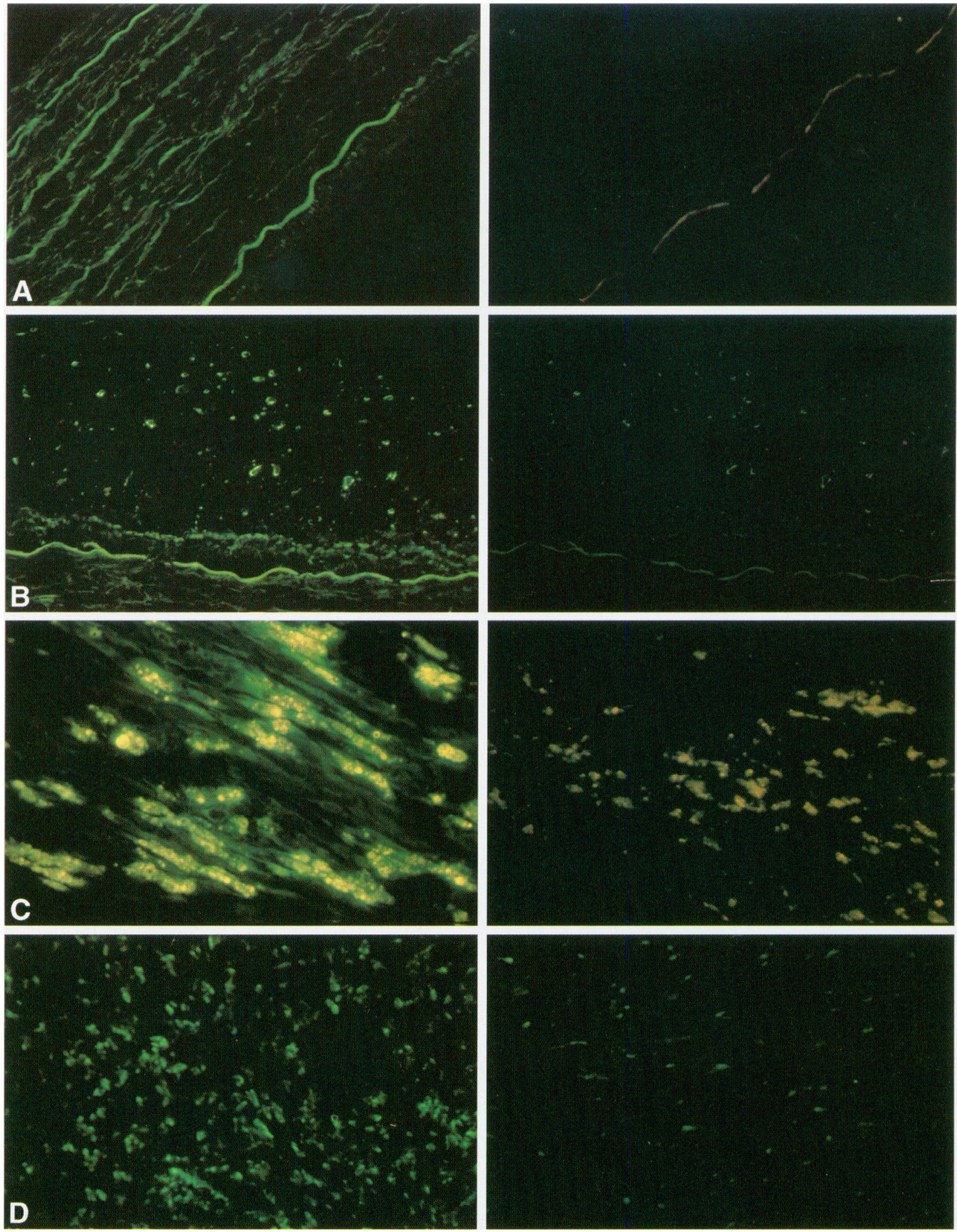

right panels), with a similar distribution pattern. In sections through dense atheroma, AGE-R 1 and -R2 were found in macrophages at the center of the plaque (Fig. 2D). In two specimens

where the plaque sections included several recanalizing blood vessels, AGE-R-IR was present in the numerous mononuclear cells and macrophages in the immediate vicinity but displayed a 
diminishing staining intensity with increasing distance from the lumen of the new vessel (Fig. 2E).

In all specimens examined, large numbers of macrophages displayed positive immunoreactivity for AGE and both AGE-R1 and AGE-R2 in adjacent sections. In all cases, intense AGE-IR (Fig. 1, left panels) and AGE-R-IR (not shown) were quite distinct from the modest autofluorescence of extracellular matrix (ECM) observed in control sections using preabsorbed or the respective preimmune IgG (Fig. 1, right panels).

\section{Serum AGE-ApoB and Tissue AGE-Collagen Levels}

Serum AGE-ApoB was significantly higher in nondiabetic patients with atherosclerotic lesions than in age-matched, non-diabetic patients without atherosclerotic lesions $(329 \pm 24$ versus $259 \pm 24 \mathrm{AGE} \mathrm{U} / \mathrm{mg}$ of ApoB, $p<0.05$ ) (Fig. 3). The latter group exhibited significantly higher levels of serum AGE-ApoB than the younger normal group $(259 \pm 24$ versus $180 \pm 19$ AGE $\mathrm{U} / \mathrm{mg}$ of $\mathrm{ApoB}, p<0.05$ ) (Fig. 3). AGE-collagen levels in carotid artery tissues from patients with atherosclerotic lesions ranged from 2.3 to 9.8 $\mathrm{U} / \mathrm{mg}$ of protein (mean $\pm \mathrm{SD}: 5.79 \pm 0.21 \mathrm{U} / \mathrm{mg}$ of protein) (Table 2).

Serum AGE-ApoB levels were compared with tissue AGE-collagen levels in the patients who underwent surgery (Table 2 ). There was a significant correlation between tissue AGE-collagen (AGE U/mg of protein) and plasma AGEApoB (AGE U/mg of ApoB) $(r=0.707, p<0.01)$ (Fig. 4). A positive correlation was also observed between tissue AGE-collagen levels (by ELISA) and AGE-IR by cytochemistry (based on semi- quantitative scoring of stained sections from each specimen): samples containing low levels of AGE per milligram (left panel) of tissue by ELISA demonstrated a correspondingly low level of AGE-specific immunofluorescence on tissue sections (Fig. 5). While high AGE-IR corresponded to greater immunostaining intensity, the latter related to greater tissue cellularity and with lesion severity, this could not be statistically ascertained. However, a similar relationship between AGE-immunofluorescence and circulating AGEApoB by ELISA was observed in this group of patients.

\section{DISCUSSION}

AGEs have been previously localized using a polyclonal anti-AGE antibody on the ECM of atheromatous arteries from diabetic patients (4) and using a monoclonal antibody in nondiabetic patients $(7,27)$. AGEs have been shown to progressively cross-link connective tissue and collagen not only in diabetes but also as a consequence of aging $(28,29)$. Such progressive accumulation of AGE products in the ECM during the normal aging process has wide-ranging implications for lesion formation and plaque acceleration, since, in addition to promoting tissue rigidity, AGEs covalently trap low-density lipoproteins within matrix components (30), promote thrombosis (31), and quench NO-mediated vasodilation (10).

It is apparent that a considerable proportion of AGE content in atherosclerotic lesions is present extracellularly, whether within the ECM or associated with cell debris in the fibrosed necrotic core. This may account for the markedly

\section{FIG. 2. AGE-receptor immunoreactivity in atheromatous human carotid artery}

(A) Left: Adhering and infiltrating mononuclear cells within the thickened intima and at the luminal side of the vessel, and carotid endothelium stained for AGE-R1. (magnification $\times 100$ ) Right: Same as in A left, stained with AGE-R2 antibody. (magnification $\times 100)(B)$ Left: Higher magnification $(\times 200)$ of an area with intimal thickening and positive staining for AGE-Rl in monocytes, migrating through the endothelium. Right: Corresponding section to that on the left, showing AGE-R2-IR with a similar distribution pattern, but more intensely staining vascular endothelium. (magnification $\times 200$ ) (C) Left: Section through vasa vasorum within an atheromatous carotid artery, AGE-Rl-IR is intense within the smooth muscle cells and endothelium. (magnification $\times 200$ ) Right: Corresponding section to $C$ left, stained with anti-AGE-R2-antibody shows a similar distribution pattern to AGE-R1. (magnification $\times 200$ ) (D) Left: Section through an area of dense atheroma of a carotid artery. AGE-RI-IR appears intense within macrophages in the center of the plaque. (magnification $\times 100$ ) Right: Corresponding section to $D$ left showing AGE-R2 of a similar distribution pattern to that of AGE-R1. (magnification $\times 100)$ (E) Left: Section through a recanalizing vessel at the center of a dense carotid plaque. Note AGE-RI-IR in the monocytes/macrophages migrating through the injured vascular endothelium. (magnification $\times 100$ ) Right: Corresponding section to that on left, AGE-R2 also stained strongly in cells infiltrating recanalizing vessel walls of dense plaques. (magnification $\times 200$ ) 

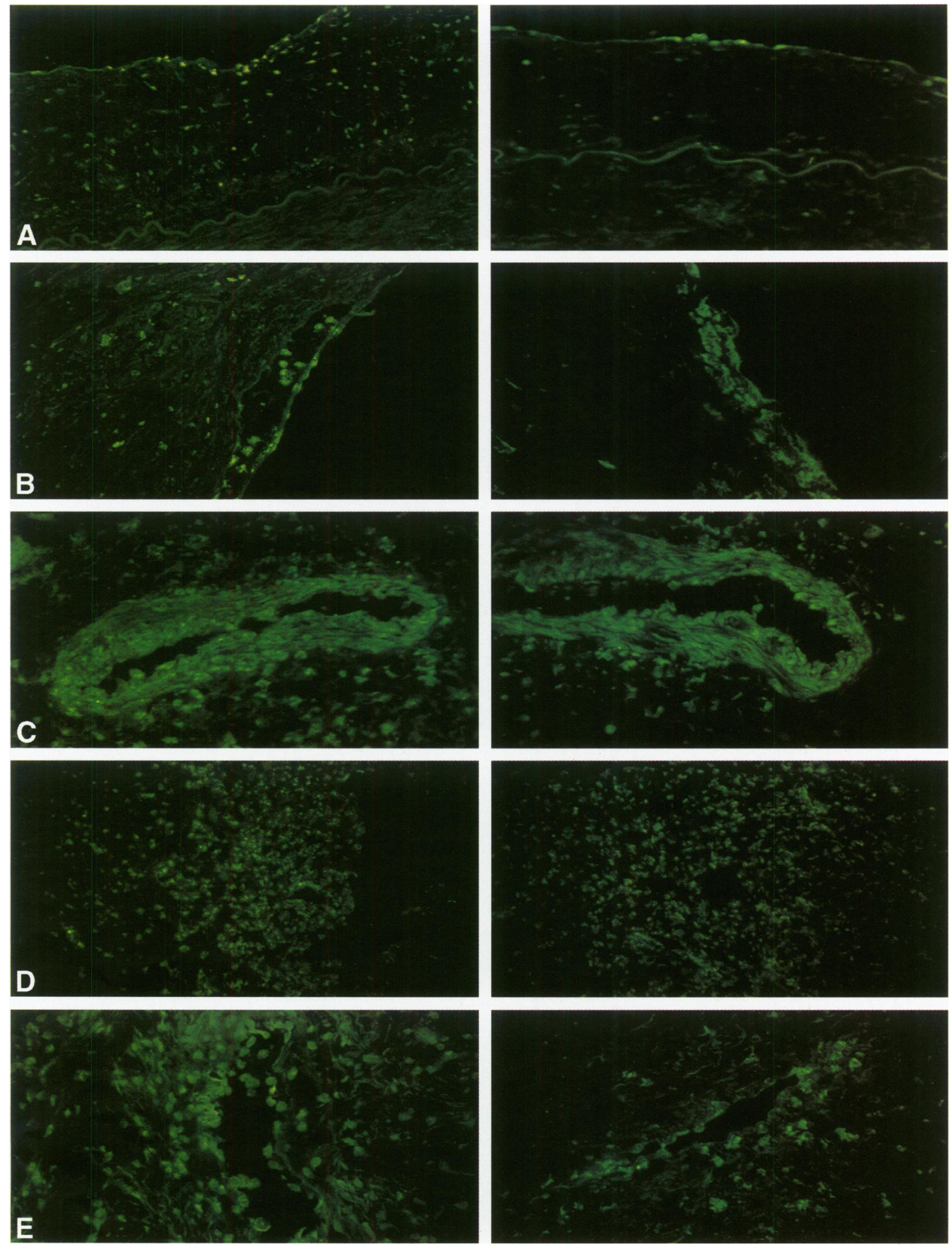

elevated levels of AGEs in advanced lesions. The validity of this result is borne out by the striking correlation between tissue AGE levels, as measured by ELISA, and the severity of lesions. It is particularly intriguing that a significant correlation exists between arterial wall AGEs and AGEmodified ApoB in the bloodstream of these patients, in view of the lack of hyperlipidemia. ApoB 


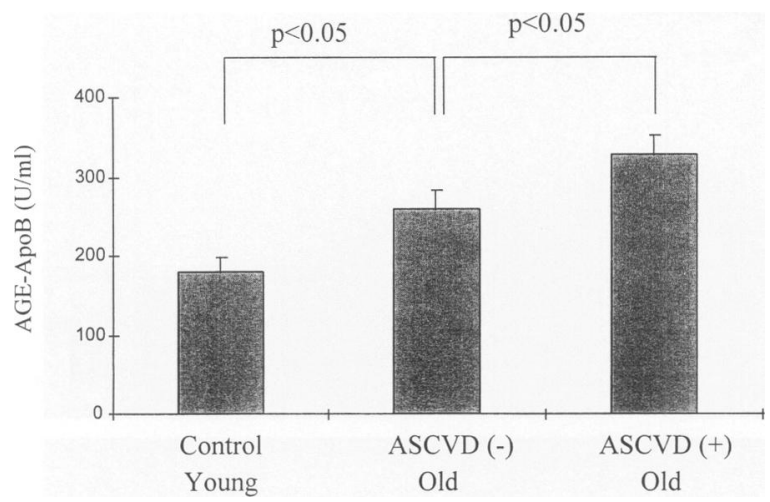

FIG. 3. Serum AGE-ApoB levels are elevated in patients with occlusive atherosclerotic vessel disease (ASCVD)

Serum AGE-ApoB was compared among patients with atherosclerotic vascular disease (ASCVD), agematched patients without ASCVD, and healthy young controls. modification by AGEs is known to be increased in diabetic and in nondiabetic patients with nephropathy (16). Presumably, this may be in part due to altered receptor recognition of the AGE-modified LDL molecule, as shown in animal studies $(32,33)$. When injected into transgenic mice expressing the human LDL receptor, AGE-ApoB failed to be cleared normally by the classic LDL receptor (14). AGE-modified serum lipoproteins are likely to be scavenged over time by either macrophages or the endothelium through a number of receptor or nonreceptor pathways, including scavenger receptors and AGE receptors. It follows that the latter may be important pathways for AGE lipid accumulation in smooth muscle cells, macrophages, and macrophage-derived foam cells.

Intracellular AGE-I has been previously demonstrated in macrophage and smooth muscle cells of fatty streak lesions (7), an observation

TABLE 2. Correlation of arterial tissue collagen AGEs and AGE-ApoB in nondiabetic patients within atherosclerotic lesions

\begin{tabular}{|c|c|c|c|c|}
\hline Patient No. & Sex & Age & $\begin{array}{c}\text { Arterial Tissue } \\
\text { Collagen AGEs } \\
\text { (U/mg) }\end{array}$ & $\begin{array}{c}\text { AGE-ApoB } \\
\text { (U/mg) }\end{array}$ \\
\hline 1 & M & 69 & 3.4 & 272 \\
\hline 2 & $M$ & 61 & 3.9 & 220 \\
\hline 3 & M & 60 & 5.7 & 390 \\
\hline 4 & M & 64 & 2.4 & 216 \\
\hline 5 & $\mathrm{~F}$ & 59 & 2.3 & 186 \\
\hline 6 & M & 63 & 4.8 & 230 \\
\hline 7 & $M$ & 68 & 6.9 & 382 \\
\hline 8 & M & 61 & 5.8 & 199 \\
\hline 9 & M & 69 & 3.7 & 220 \\
\hline 10 & $\mathrm{~F}$ & 64 & 5.4 & 484 \\
\hline 11 & M & 52 & 9.8 & 469 \\
\hline 12 & M & 70 & 7.2 & 469 \\
\hline 13 & $\mathrm{~F}$ & 75 & 7.6 & 473 \\
\hline 14 & $\mathrm{~F}$ & 85 & 7.6 & 344 \\
\hline 15 & M & 81 & 7.8 & 382 \\
\hline 16 & $M$ & 68 & 6.3 & 421 \\
\hline 17 & $\mathrm{~F}$ & 74 & 7.2 & 412 \\
\hline 18 & M & 66 & 2.9 & 168 \\
\hline 19 & M & 78 & 6.8 & 394 \\
\hline 20 & $M$ & 73 & 6.2 & 233 \\
\hline 21 & $\mathrm{~F}$ & 79 & 7.7 & 350 \\
\hline Mean $\pm S D$ & $15 \mathrm{M} / 6 \mathrm{~F}$ & $68.5 \pm 8.2$ & $57.95 \pm 2.06$ & $329.24 \pm 108.54$ \\
\hline
\end{tabular}




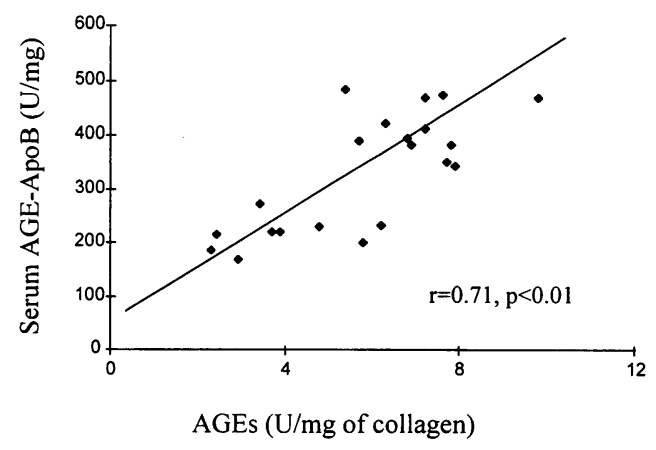

FIG. 4. Correlation between arterial tissue AGE-collagen and circulating serum AGE-ApoB levels in non-diabetic patients with ASCVD disease

Tissue AGE-collagen and serum AGE-ApoB levels were measured by ELISA as described. Data represent the mean $\pm \mathrm{SD}$ of triplicate measurements. There was a significant correlation between tissue AGE-collagen $(\mathrm{U} / \mathrm{mg})$ and plasma AGE-ApoB (U/mg) $(r=0.707, p<0.01)$.

which is confirmed in the current investigation and which is consistent with active uptake of AGE proteins or AGE lipids by these cell types. While macrophages are obligate phagocytes, the normally quiescent smooth muscle cells undergo a phenotypic change as atherosclerotic lesions progress (34). Such transformed smooth muscle cells are known to express scavenger receptors, accumulate lipid in early lesions, and evolve into foam cells in late lesions (35). The proximity of AGEs and lipid deposits within smooth muscle cells in a number of tissue sections from different patients suggests a close interaction between AGEs and lipid deposits during atheroma formation. This may reflect either a lipid peroxidationenhanced AGE formation, or advanced glycation-mediated lipid peroxidation, or both, in a two-way positive feedback manner (36). Several cell-associated or soluble AGE-binding proteins have also been described, including RAGE (37), lysozyme (22), lactoferrin (21), galectin-3 (19), and scavenger receptors (33), each possibly binding to different subclasses of AGE moities and eliciting distinct cellular responses. This, however, remains uncertain at the present.

In the current investigation, we determined that cells within atheromatous lesions possess two AGE-receptor proteins, AGE- $\mathrm{R}_{1}$ and AGE$R_{2}$, which may participate in the receptor-mediated uptake of AGE proteins and AGE lipids. These molecules are found on the plasma membrane of many cell types (18). The distinct local-
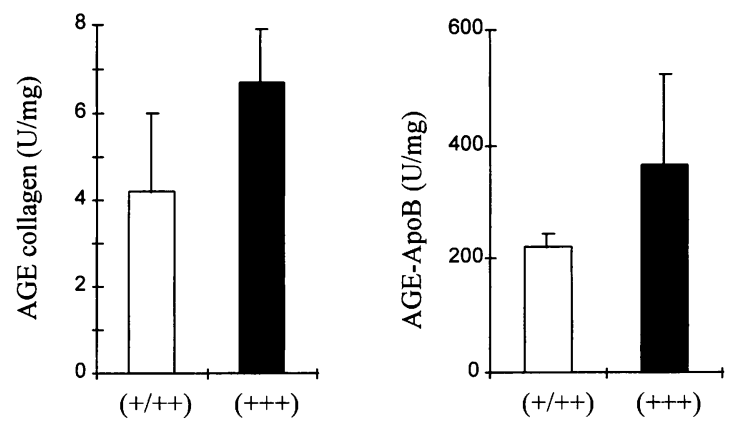

FIG. 5. Relationship of tissue AGE deposition by immunohistochemistry and circulating AGE-ApoB in non-diabetic patients with ASCVD

AGE-IR in each section was scored semi-quantitatively as described. Left panel: A positive relationship was observed between arterial tissue AGE levels (U/mg of collagen) and the semi-quantitative data of AGE immunostaining in the same tissue sample. Right panel: A similar relationship was also observed between serum AGE-ApoB levels (U/mg) and the semi-quantitative AGE immunostaining data.

ization of these proteins to endothelial and mononuclear cells in early atheroma suggest that they may play a role in cellular recognition of circulating and tissue-bound AGEs. The detection of AGE receptors on adherent monocytes as well as on those in the thickened intima and around recanalizing vessels of plaques is significant, and it suggests that these cells respond to the presence of tissue AGEs by binding and endocytosing AGEs as they infiltrate tissues. Similar properties have been demonstrated in vitro and in vivo, either as increased expression of adhesion molecules on edothelium (6) or in the form of monocytic chemotaxis in response to AGEs (38). Activated macrophages, occuring deep in atheromatous lesions, appeared enriched in both AGE and AGE-receptor immunoreactivity, which is consistent with the presumed role of these cells in scavenging AGEs (23), along with other modified molecules such as oxidatively modified LDL (ox-LDL) $(39,40)$.

The pathogenesis of atherosclerosis is marked by its complex and multifactorial nature. This is typified by a heterogeneous clinical and pathological presentation among different patients and among vessels. This study has demonstrated a correlation between AGEs in tissues and a quantifiable serum protein (AGE-ApoB) which may provide a tool for the early detection of susceptible individuals at a time when lipid profiles or glycemia raise no alarming concerns. 


\section{ACKNOWLEDGMENTS}

This work was funded by a British Diabetic Association fellowship (A.W.S.) and by National Institutes of Health Grants AG09453 and AG06943 (to H.V.).

\section{REFERENCES}

1. Vlassara H, Bucala R, Striker L. (1994) Pathogenic effects of advanced glycosylation endproducts: biochemical, biologic, and clinical implications for diabetes and aging. Lab. Invest. 70: 138-151.

2. Vlassara H, Fuh H, Makita Z, Krungkrai S, Cerami A, Bucala R. (1992) Exogenous advanced glycosylation endproducts induce complex vascular dysfunction in normal animals: A model for diabetic and aging complications. Proc. Natl. Acad. Sci. U.S.A. 89: 12043-12047.

3. Reiser KM. (1991) Nonenzymatic glycation of collagen in aging and diabetes. Proc. Soc. Exp. Biol. Med. 196: 17-29.

4. Nakamura Y, Horii $Y$, Nishino T, et al. (1993) Immunohistochemical localization of advanced glycosylation endproducts (AGEs) in coronary atheroma and cardiac tissue in diabetes. Am. J. Pathol. 143: 1649-1656.

5. Palinski W, Koschinsky T, Butler SW, et al. (1995) Immunological evidence for the presence of advanced glycosylation endproducts products in atherosclerotic lesions of euglycemic rabbits. Arterioscler. Thromb. Vasc. Biol. 15: 571-582.

6. Vlassara H, Fuh H, Donnelly T, Cybulsky M. (1995) Advanced glycation endproducts promote adhesion molecule (VCAM-1, ICAM-1) expression and atheroma formation in normal rabbits. Mol. Medicine 1: 447-456.

7. Kume S, Takeya M, Mori T, et al. (1995) Immunohistochemical and ultrastructural detection of advanced glycation endproducts in atherosclerotic lesions of human aorta with a novel specific monoclonal antibody. Am. J. Pathol. 147: 654-667.

8. Lee WK, Bell J, Kilpatrick E, Hayes M, Lindop GB, Dominiczak MH. (1993) Collagenlinked fluorescence in human atherosclerotic plaques. Atherosclerosis 98: 219-227.

9. Sell DR, Lapolla A, Odetti P, Fogarty J, Monnier VM. (1992) Pentosidine formation in skin correlates with severity of complications in individuals with long-standing IDDM. Diabetes 41: 1286-1292.

10. Bucala R, Tracey KJ, Cerami A. (1991) Ad- vanced glycosylation products quench nitric oxide and mediate defective endotheiumdepenedent vasodilatation in experimental diabetes. J. Clin. Invest. 87: 432-438.

11. Imani F, Horii Y, Suthanthiran M, et al. (1993) Advanced glycosylation endproduct-specific receptors on human and rat T-lymphocytes mediate synthesis of interferon gamma: Role in tissue remodelling. J. Exp. Med. 178: 2165-2172.

12. Ross R. (1993) The pathogenesis of atherosclerosis: A perspective for the 1990s. Nature 362: 801-809.

13. Bucala R, Makita Z, Koschinsky T, Cerami A, Vlassara H. (1993) Lipid advanced glycosylation: pathway for lipid oxidation in vivo. Proc. Natl. Acad. Sci. U.S.A. 90: 6434-6438.

14. Bucala R, Makita Z, Vega G, et al. (1994) Modification of low-density lipoprotein by advanced glycation endproducts contributes to the dyslipidemia of diabetes and renal insufficiency. Proc. Natl. Acad. Sci. U.S.A. 91: 9441-9445.

15. Bucala R, Mitchell R, Arnold K, Innerarity $T$, Vlassara $\mathrm{H}$, Cerami A. (1995) Identification of the major site of apolipoprotein B modification by advanced glycation endproducts blocking uptake by the low density lipoprotein receptor. J. Biol. Chem. 270: 10828-10832.

16. Fishbane S, Bucala R, Pereira JG, Giordano D, Founds H, and Vlassara H. (1997) Reduction of plasma apolipoprotein-B by effective removal of circulating glycation derivatives in uremia. Kidney Int. (In press).

17. Yang Z, Makita Z, Horii Y, et al. (1991) Two novel rat liver membrane proteins that bind advanced glycosylation endproducts: Relationship to macrophage receptor for glucosemodified proteins. J. Exp. Med. 174: 515-524.

18. Li YM, Mitsuhashi T, Wojciehowicz D, et al. (1996) Molecular identity and cellular distribution of advanced glycation endproduct receptors: Relationship of p60 to OST-48 and p90 to $80 \mathrm{~K}-\mathrm{H}$ membrane proteins. Proc. Natl. Acad. Sci. U.S.A. 93: 11047-11052.

19. Vlassara H, Li YM, Imani F, et al. (1995) Identification of galectin-3 as a high affinity binding protein for advanced glycation endproducts (AGE): A new member of the AGEreceptor complex. Mol. Medicine 1: 634-646.

20. Neeper M, Schmidt AM, Brett J, et al. (1992) Cloning and expression of a cell surface receptor for advanced glycosylation endproducts of proteins. J. Biol. Chem. 267: 14998-15004.

21. Schmidt AM, Vianna $M$, Gerlach $M$, Brett J, Ryan J, Kao J. (1992) Isolation and characterization of two binding proteins for advanced 
glycosylation end products from bovine lung which are present on the endothelial cell surface. J. Biol. Chem. 256: 14987-14997.

22. Li YM, Tan A, Vlassara H. (1995) Antibacterial activity of lysozyme and lactoferrin is inhibited by binding of advanced glycationmodified proteins to a conserved motif. $\mathrm{Na}$ ture Med. 1: 1057-1061.

23. Vlassara $H$, Brownlee $M$, Manogue KR, Dinarello C, Pasagian A. (1988) Cachectin/TNF and IL- 1 induced by glucose modified proteins: Role in normal tissue remodelling. Science 240: 1546-1548.

24. Vlassara H. (1992) Receptor mediated interactions of advanced glycosylation endproducts with cellular components within diabetic tissues. Diabetes 41 (Suppl 2): 52-56.

25. Makita Z, Vlassara H, Cerami A, Bucala R. (1992) Immunochemical detection of advanced glycosylation endproducts in vivo. J. Biol. Chem. 267: 5133-5138.

26. Makita Z, Radoff S, Rayfield EJ, et al. (1991) Advanced glycosylation endproducts in patients with diabetic nephropathy. New. Engl. J. Med. 325: 836-842.

27. Hunt JV, Skamaruskas JT, Mitchinson MJ. (1994) Protein glycation and fluorescent material in human atheroma. Atherosclerosis 111: 255-265.

28. Schnider SL, Kohn RR. (1982) Effects of age and diabetes mellitus on the solubility of collagen from human skin, tracheal cartilage and dura mater. Exp. Gerontol. 17: 185-194.

29. Monnier VM, Kohn RR, Cerami A. (1984) Accelerated age-related browning of human in diabetes mellitus. Proc. Natl. Acad. Sci. U.S.A. 81: 583-587.

30. Brownlee $M$, Pongor S, Cerami A. (1983) Covalent attachment of soluble proteins by nonenzymatically glycosylated proteins collagen: Role of soluble immune complexes. $J$. Exp. Med. 158: 1739-1744.

31. Esposito C, Gerlach H, Brett J, Stern D, Vlassara H. (1989) Endothelial receptor-mediated binding of glucose-modified albumin is associated with increased monolayer permeability and modulation of cell surface coagulant properties. J. Exp. Med. 170: 1387-1407.

Communicated by R. Cotran. Accepted June 22, 1997.
32. Goldstein JL, Ho YK, Basu SK, Brown MS. (1979) Binding site on macrophages that mediates uptake and degradation of acetylated low density lipoproteins producing massive cholesterol deposition. Proc. Natl. Acad. Sci. U.S.A. 76: 333-337.

33. Fogelman AM, Haberland ME, Seager J, Hokom M, Edwards PA. (1980) Factors regulating the activities of the low density lipoprotein receptor and the scavenger receptor on human monocytes-macrophages. $J$. Lipid Res. 22: 1131-1141.

34. Thyberg J, Hedin U, Sjolund M, Palmberg L, Bottger BA. (1990) Regulation of differentiated properties and proliferation of arterial smooth muscle cells. Arteriosclerosis 10: 966990.

35. Luoma J, Hitunen T, Sarkioja T, et al. (1994) Expression of alpha-2 macroglobulin receptor/ low density lipoprotein receptor-related protein and scavenger receptor in human arterosclerotic lesions. J. Clin. Invest. 93: 2014-2021.

36. Lyons TJ. (1993) Glycation and oxidation: a role in the pathogenesis of atherosclerosis. Am. J. Cardiol. 171: 26B-31B.

37. Schmidt AM, Hori O, Brett J, Yan SD, Wautier JL, Stern D. (1994) Cellular receptors for advanced glycation endproducts. Implications for induction of oxidative stress and cellular dysfunction in the pathogenesis of vascular lesions. Arterioscler. Thromb. 14: 1521-1528.

38. Kirstein M, Brett J, Radoff S, Ogawa S, Stern D, Vlassara H. (1990) Advanced glycosylation induces transendothelial human monocyte chemotaxis and secretion of plateletderived growth factor: Role of vascular disease of diabetes and aging. Proc. Natl. Acad. Sci. U.S.A. 87: 9010-9014.

39. Li H, Freeman MW, Libby P. (1995) Regulation of smooth muscle cell scavenger receptor expression in vivo by atherogenic diets and in vitro by cytokines. J. Clin. Invest. 95: 122-133.

40. Ismail NA, Alavi MZ, Moore S. (1994) Lipoprotein-proteoglycan complexes from injured rabbit arotas accelerate lipoprotein uptake by arterial smooth muscle cells. Atherosclerosis 105: 79-87. 